$21-1133$

LA-5808-MS

Informal Report

UC-71

Reporting Dato: Novomber 1974 Isoued: Docember 1974

\title{
Investigation of DOT Specification \\ 2R Containers to Meet Special Form Certification
}

by

R. W. Andrae 
In the interest of prompt distribution, this LAMS zeport was not odited by the Technical Intormation staft.

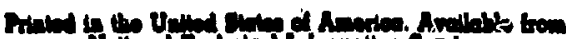

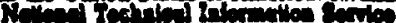

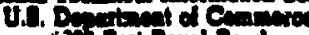

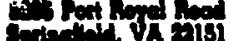

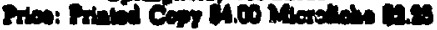

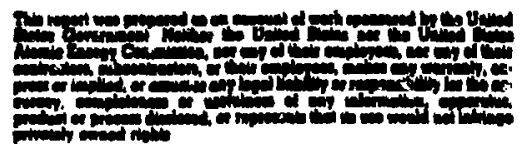




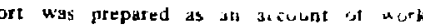
sponsored by the Uniled Stules t...ererninent. Nevther the United States nos the loited states Aturnuc Ener oy Commission, nor any of their eniclusect oor any their contractors, subcontractors, or heis

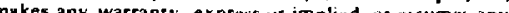
mukes any warranty, express ur implied, os essumes any legal liablity or responsibility for the accuracy, com. pleteness or usefulness of any informistion, apparatus. produet or process disclosed, ur represents that its use mould not infringe privately owned rishts.

\title{
INVESTIGATION OF DOT SPECIFICATION 2R CONTAINERS
}

TO MEET SPECIAL FORM CERTIFICATION

by

R. W. Andrae

\section{ABSTRACT}

\begin{abstract}
A test program was conducted to investigate the qualifications of $2 \mathrm{R}$, pipe nipple-cap type containers as a spectal form encapsulation. The testing fncluded a 30-foot $(9.14-\mathrm{m})$ drop, impact with a $3-1 \mathrm{~b}(1.36-\mathrm{kg})$ weight, hearing to $1475^{\circ} \mathrm{F}(1075 \mathrm{~K})$ and immersion in water, as specified in the DOT Spec., Par. 173.398. Results indicate that the use of the $2 R$, pipe nipple-cap container as a special form encapsulation should probably be restricted to the shipment of solids and then only under the conditions that soluble solids are adequately protected by an Inner container.
\end{abstract}

\section{INTRODUCTION}

Radioactive materials can be packaged for shipment by common carrier much more conveniently when the material meets special form criteria as defined by the DOT Specification. Spectal form can be attained either by having the material itself in massive solid form, or by virtue of its encapsulation. This report is concerned with the latter, encapsulation; and in particular with pipe nipple-cap type containment meeting the DOT Specification 2R.

It has been our judgment at LASL that the use of the 2R, pipe nipple-cap container as a special form encapsulation should be restricted to the shipment of Insoluble solids and not 1iquids or gases because of the uncertainty of the leak tightness of the threaded joints. Even such limited usage, however, must soon be supported by appropriate documentation affiring that the special form criteria have been met. Because the DOT Specifications only stipulace the performance specifications for qualification and not the desiga details of a container to provide compliance, the continued use of $2 R$ contaita:ers as a special form encapsulation is dependent upon adequate test data showing their response to conditions of interest.
We also did a limitsd amount of testing of $2 R$ flanged type closure containers to determine whether or not this type of closure was superior (only the heating and immersion tests were performed).

\section{DISCUSSION}

As a practical expediency, the test specimens in this study did not contain any radioactive substance. The determination as to whether or not test-incurred damage meant the possible release of radioactivity in an actual case was a matter of interpretation of the test data. Obviously, the loss of a cap or the fracture of the container walls would represent very serious damage, but this would be easily detected by a physical examination of the tested article. Just a 'oosening of the cap, on the other hand, was a more subtie fart of damage that could be sertous and reguired further evaluation. Three such measurements, each involving a different medium, were used for this purpose at various points in the test program. Theso were (1) leak rates for hel1 $\mathrm{m}$, (2) leak rates for $\mathrm{a1r}$, and (3) the amount of water leaked in during a 24-hour period. The hellum leak test is by far the most sensitive technique used. 


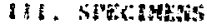

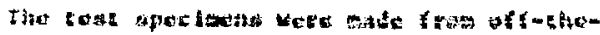

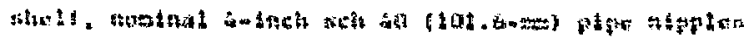

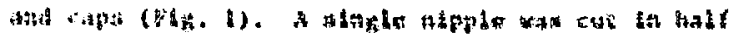

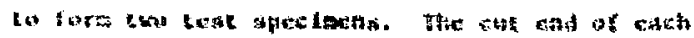

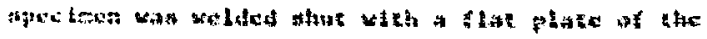

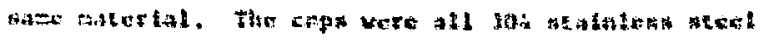

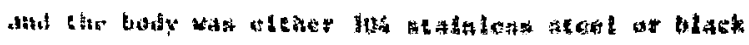

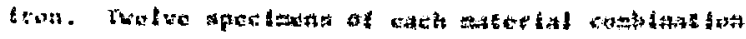

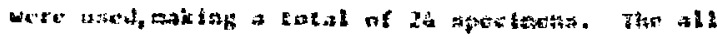

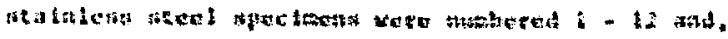

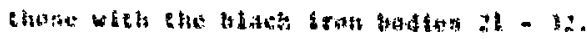

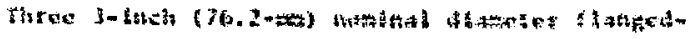

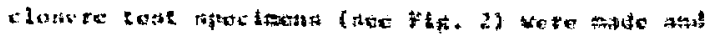

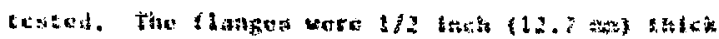

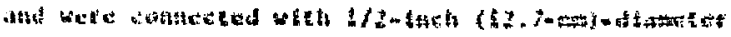

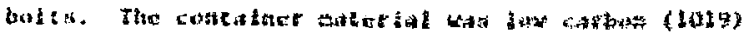
stoet.

\section{IV. dibitiths}

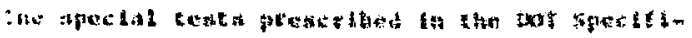

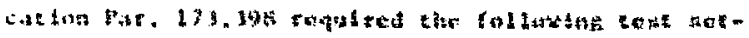

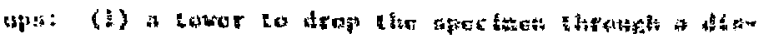

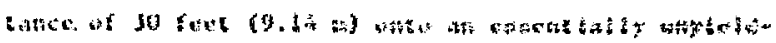

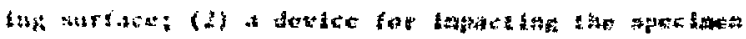

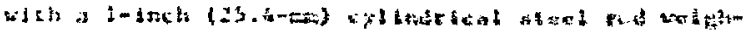

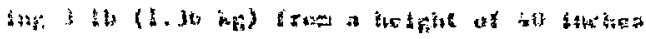

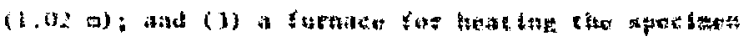

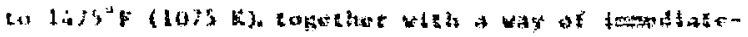

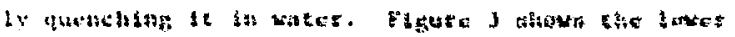

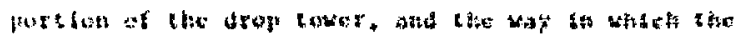

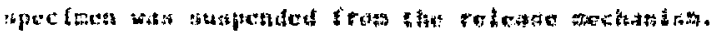

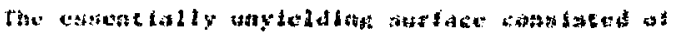

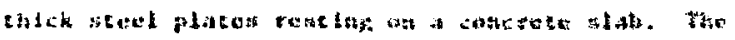

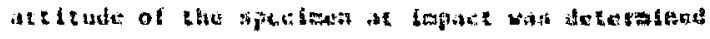

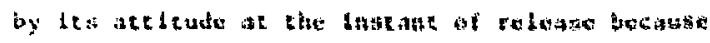

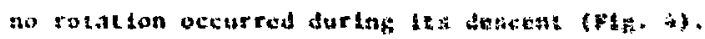

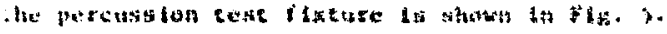

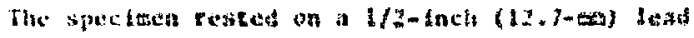

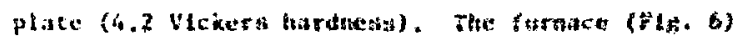
had a chan shell arrangerene whereby bie heated

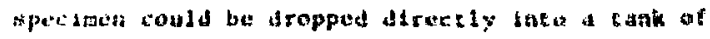
wisere

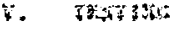

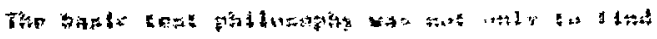

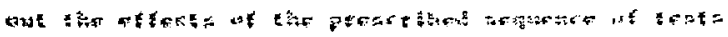
טม

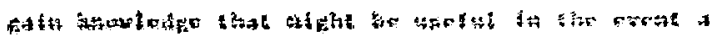

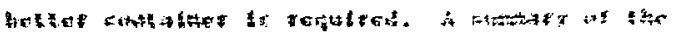
cot proter

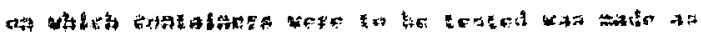

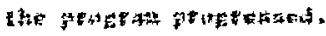

F新

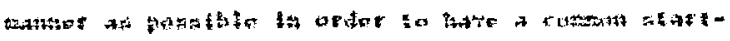

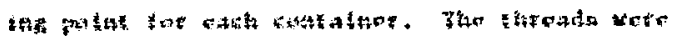

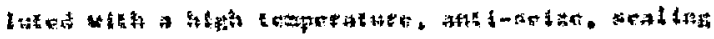

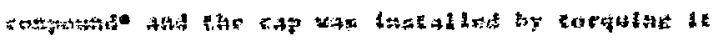
to dot

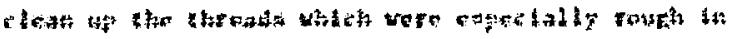

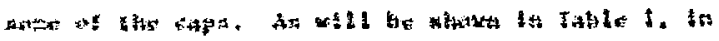

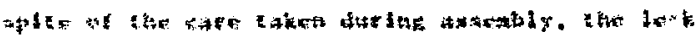

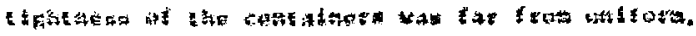

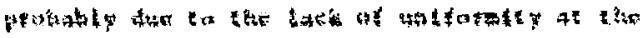
Aht

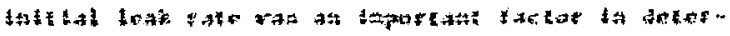

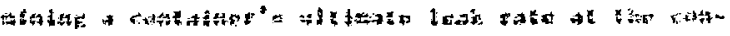

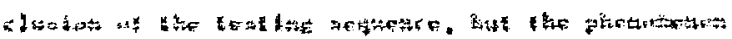

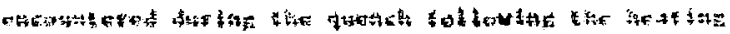

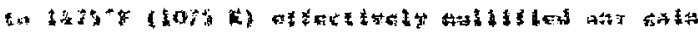

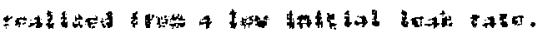

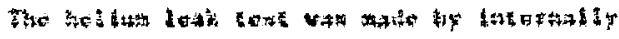

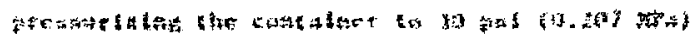

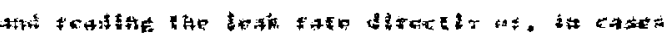

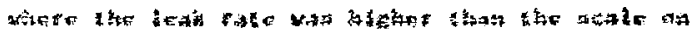

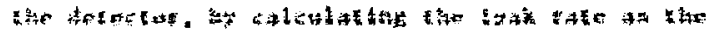

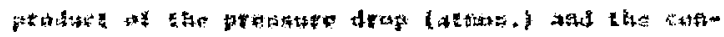

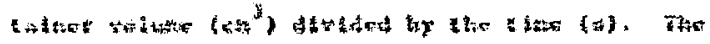

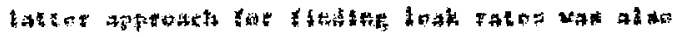

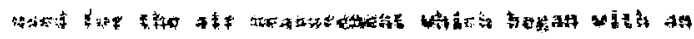

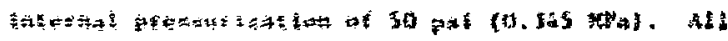

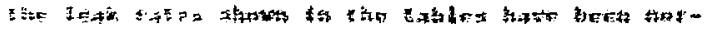

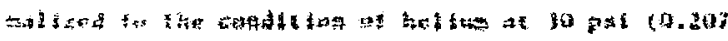
$+4$

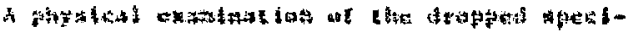

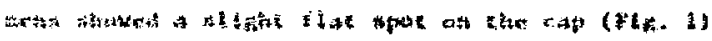

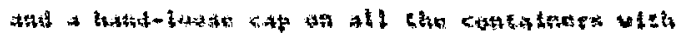




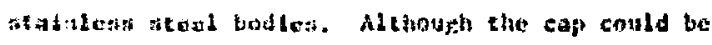

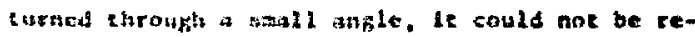

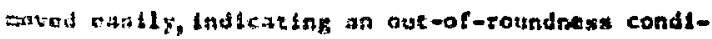
than hat ostugred. Thble I slsoy the iffects of the dtop on bokb the leak races and the sount of warer takus on during a 24 mbous twarston. The leak rates vero highor after tho tom, as indicated by the alr

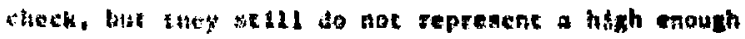
valute for waker loakago. A possible clue to account tor the beter porformatice of the contafate with

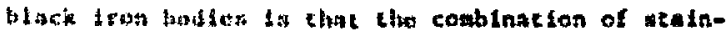

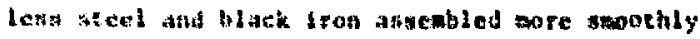

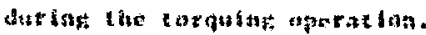

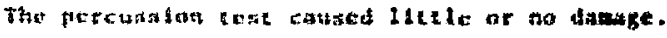

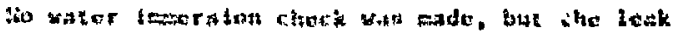

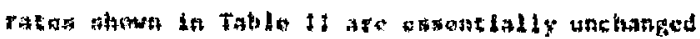
an if rewate of this test. The flat, ctreutar ent of che riced red lepacind the cantatane on the budy fotet betos the rap.

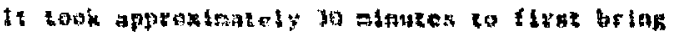

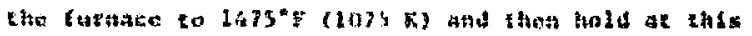

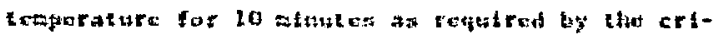

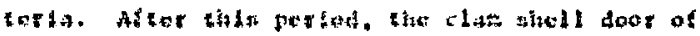

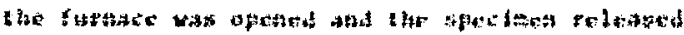

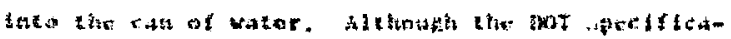

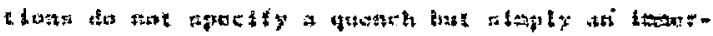

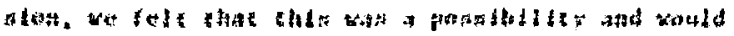

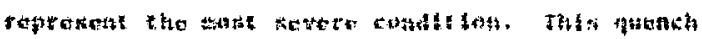

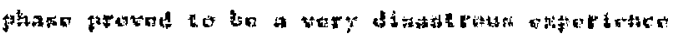

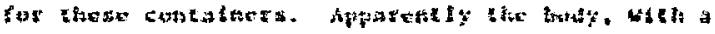

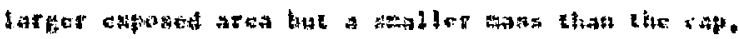

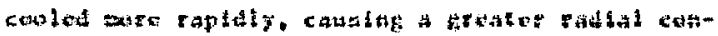

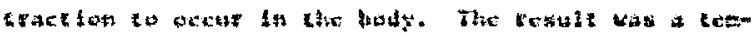

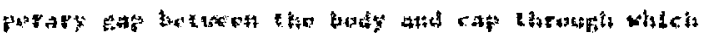

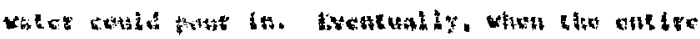

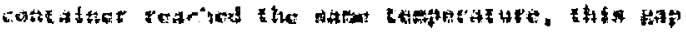

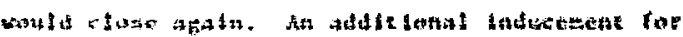

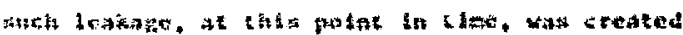

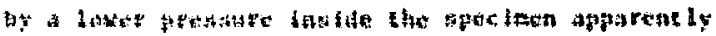

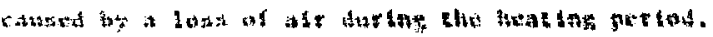

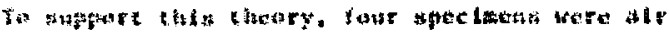

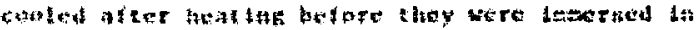

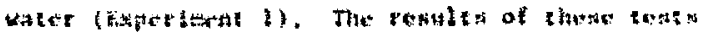

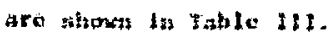

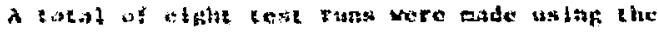

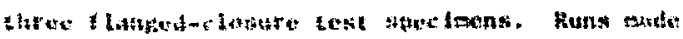

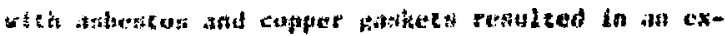

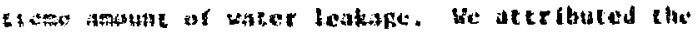

prianry cause of tills leakage to a loose-pisaich condielon after the ceite, mparenely resulelng fros permanane ganket deformatori. A subber of differane chinge vere cried. Subsequent runs wore node wich stainlest stesl bolt, no gasker, and a cods 2.04 flange design Incerporating a lead das. The butic results ware an lat water leakage over a perfod of 24 houts for the "no gankel" and "lead das" runs.

\section{vi. Streary aty cosclusiosis}

The spectal ceses preacrlbed in Par. 133.398 of che bot speeffleation veru serictly adicered to In terelatg a particular 2k, plpe alpple-cap costalner configuracton to find out whther of no: this contalner aset the spectal foro encriptiulation irtcerta. On the bas ls of the test data, the following conclusion was reachod:

A 2R plpe nipple-cop concalner sade wist a hialaless sced eap and having clchcr a stulnlests teel or black fron body can be consldered a poctal tor cheapsulaclon, providing it 13 used for the sindpeent of selfds only, and. (urther. If these solfds are water soluble, thoy are adequately protected by an inar costalser. 12 should be noted that the probles of cricicaltey can be arolded if the shipsent is conrined to a stople efneatnar whose inner diametar 18 lexy elisin 5 lnclues (127 E).

The ceats on the flanged-closure speciacns, alehusfits very lifaled, wecmed to indicate that this cype of chosure was noc affeced by che "quench." but citsountered sobe probleen during: the heating phane texelf.

Finalby, we concluded lhat wherest the leak

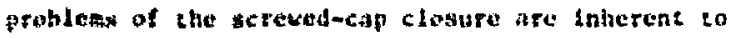

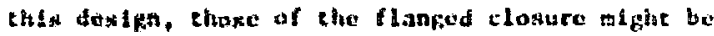
owereome throukh relatively sifple nodifications.

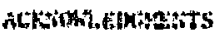

Alt of the cest inf was done at the $W^{\prime-3}$ prop Tover atte ander the supervisiza of Forma $k$. fieraulte (4x-3). Hellise leak races were detarained ah the wh-1 facidites by patt y. Dugan. 
TABLE 1

EFEECT OF DROP TEST
TABLE II

EFFECT OF PERCUSSION TEST

\begin{tabular}{|c|c|c|c|}
\hline \multirow[t]{2}{*}{$\begin{array}{l}\text { Specimelı } \\
\text { Number }\end{array}$} & \multicolumn{2}{|c|}{$\begin{array}{l}\text { Leok Roles } \\
\text { Before Test }\end{array}$} & $\begin{array}{l}\text { Leak Roles } \\
\text { After Test }\end{array}$ \\
\hline & $\mathrm{He}^{\mathrm{cm}}$ & & $\mathrm{cm}^{3} / \mathrm{s}$ \\
\hline 1 & & 270 & 250. \\
\hline 3 & & 45. & 1600. \\
\hline 4 & & 40. & 36. \\
\hline 5 & $<1.8 \times 10-10$ & 0.42 & 1.5 \\
\hline 6 & $<2.1 \times 10^{-10}$ & 0.0 & 0.0 \\
\hline 7 & & 20. & 4.4 \\
\hline 8 & & 640. & 800 \\
\hline 10 & & 914. & 1100 \\
\hline $\mathrm{Ii}$ & & 61. & 200. \\
\hline 12 & & 256. & 400. \\
\hline 21 & & 7.1 & 11. \\
\hline 22 & & 7.3 & 17. \\
\hline 23 & & 142. & 80. \\
\hline 24 & & 6.7 & 4.7 \\
\hline 25 & & 21. & 74. \\
\hline 26 & & 7.3 & 2.8 \\
\hline 27 & 0.057 & 0.027 & 0.0 \\
\hline 29 & & 11. & 20. \\
\hline 31 & & 4.4 & 6.3 \\
\hline 32 & 0.11 & 0.11 & 0.029 \\
\hline
\end{tabular}

TABLE III

EFFECT OF HEAT-QUENCH TEST

\begin{tabular}{|c|c|c|c|c|}
\hline \multirow[t]{2}{*}{$\begin{array}{l}\text { Specimen } \\
\text { Number }\end{array}$} & $\begin{array}{l}\text { Leak Rale } \\
\text { Before Test }\end{array}$ & \multicolumn{2}{|c|}{$\begin{array}{l}\text { Waler Lecked } \\
\text { over } 24 \mathrm{~h}\end{array}$} & \multirow[t]{2}{*}{ Remuks } \\
\hline & $\mathrm{He} \mathrm{cm}^{3 / \mathrm{s}}$ Air & 9 & $\%$ & \\
\hline 2 & $<1.6 \times 10^{-10}$ & 468 & 36. & \\
\hline 9 & $<1.6 \times 10^{-10}$ & 377. & 29. & \\
\hline 28 & $<2.0 \times 10^{-10}$ & 936. & 72. & Wnlested \\
\hline 30 & $<1.9 \times 10^{-10}$ & 975. & 75. & \\
\hline 5 & 1.5 & 429. & 33. & \\
\hline 6 & 00 & 468. & 36. & Pericussion \\
\hline 27 & 0.0 & 975. & 75. & anlu \\
\hline 32 & 0.03 & 910. & 70. & \\
\hline
\end{tabular}

Experimen! 1

$\left.\begin{array}{rrrr}11 & 200 & 130 . & 10 . \\ 12 & 400 & 136.5 & 10.5 \\ 26 & 2.3 & 23.4 & 1.8 \\ 31 & 6.3 & 10.4 & 0.8\end{array}\right\}$ Air cooled




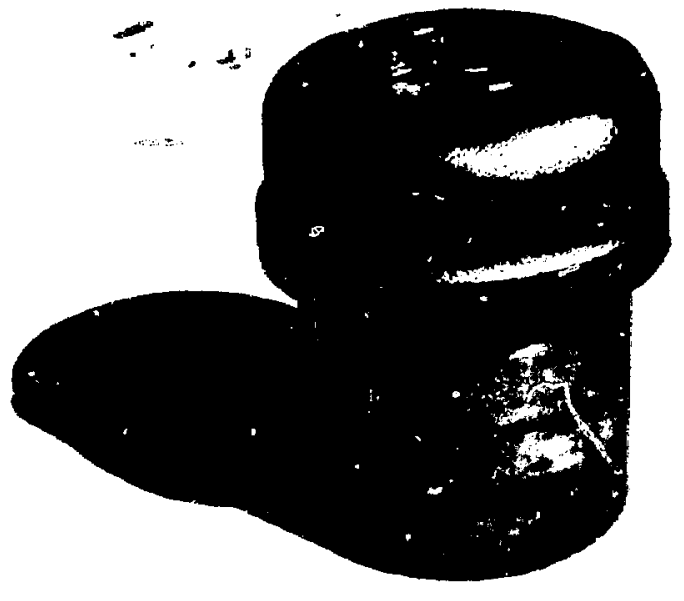

Fig. 1. P1pe nipple-cap container after 30-foot (9.14-n) drop.

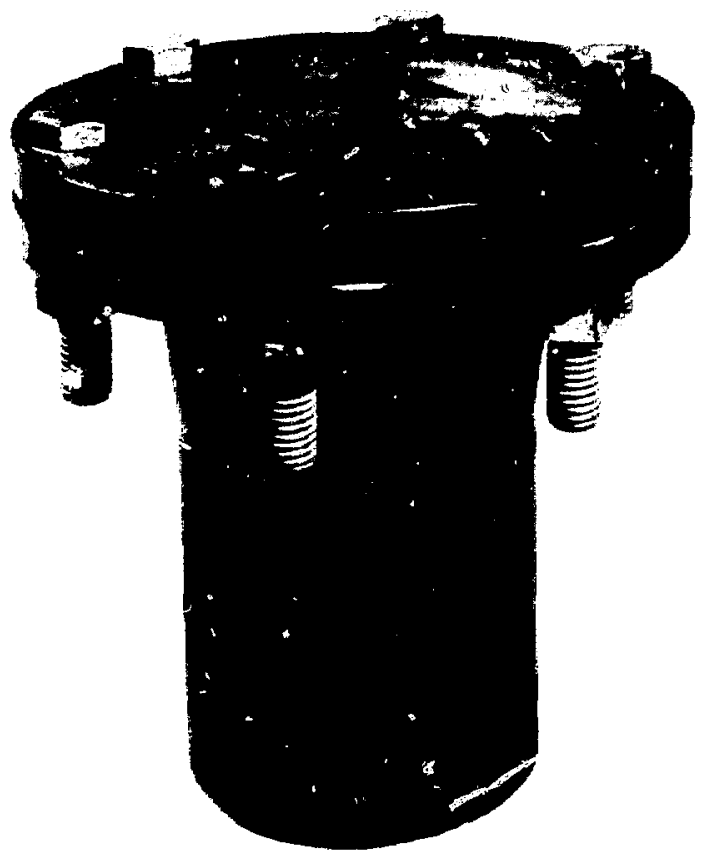

F18. 2. Flanged closure test container after fire teat.

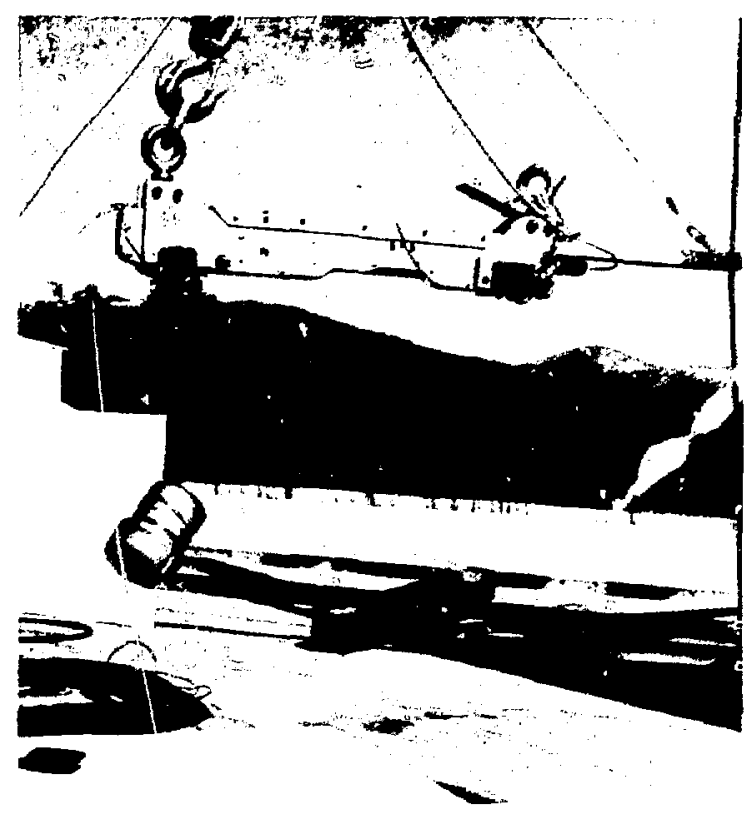

F1g. 3. spectmen aupended from release hechanism oi drop tower.
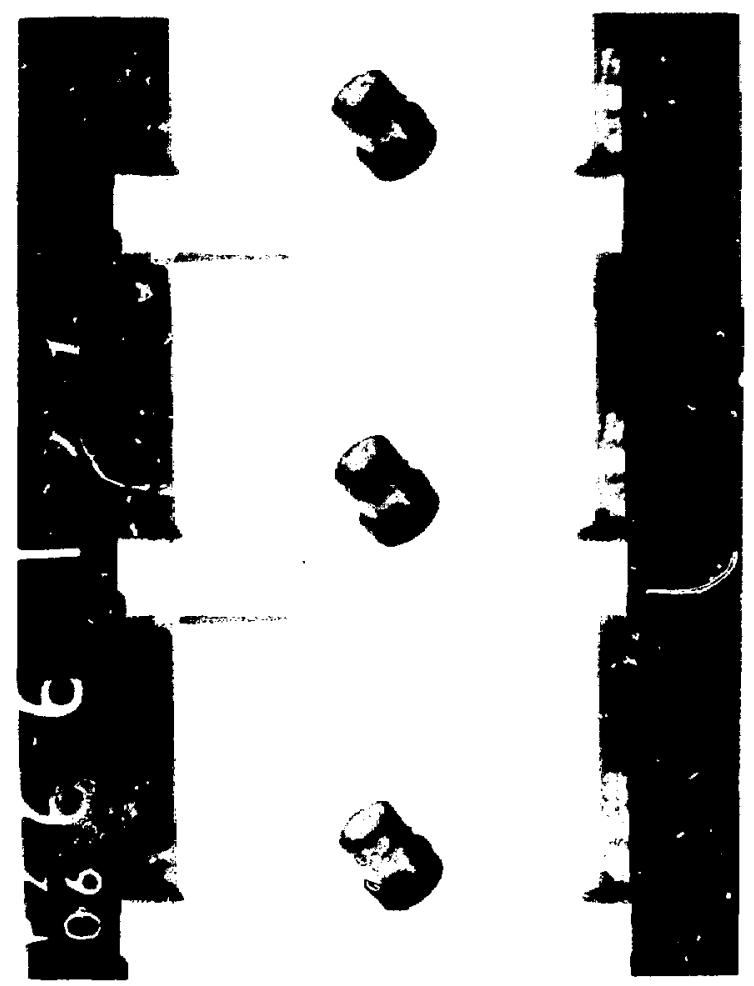

Fig. 4. Specimen impacting. 


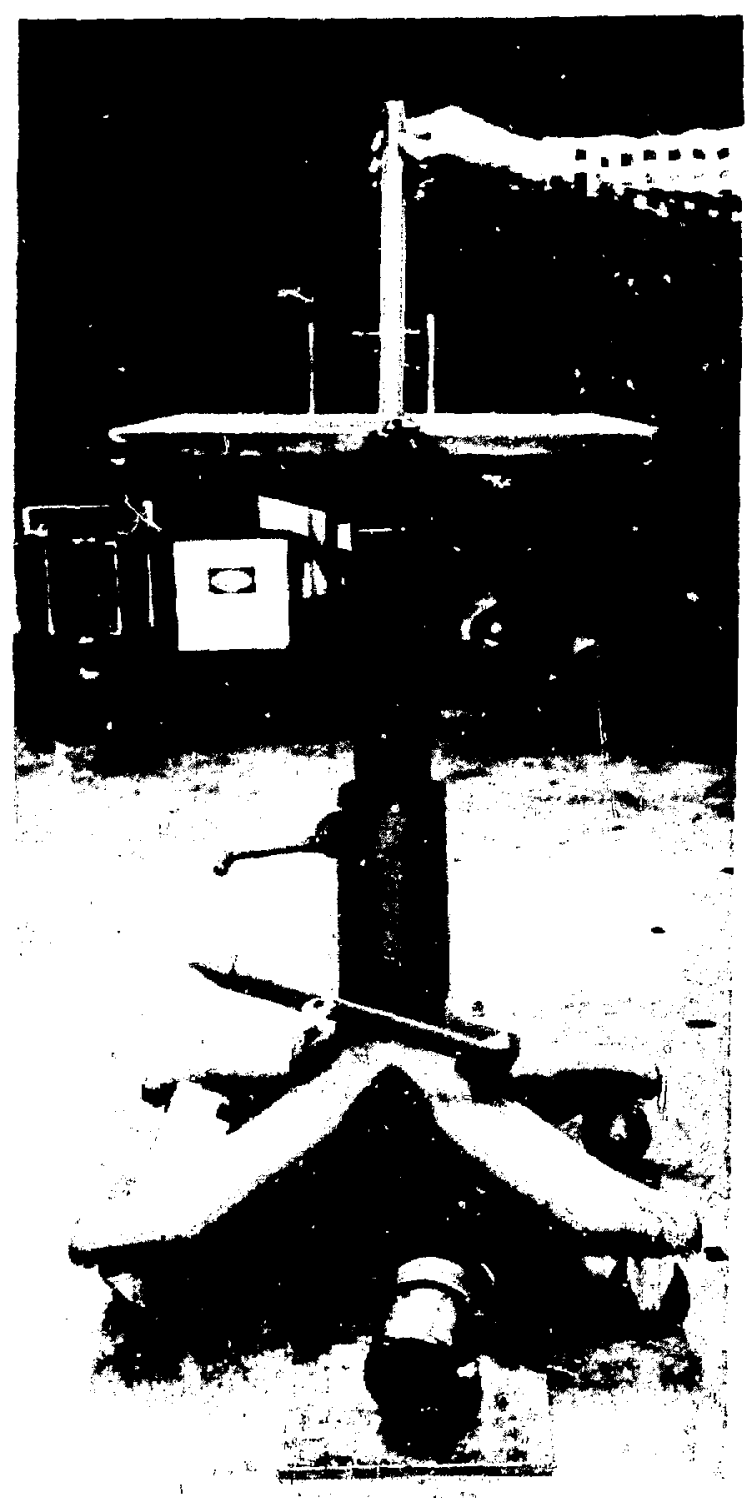

Fig. 5. Percussion test secup.

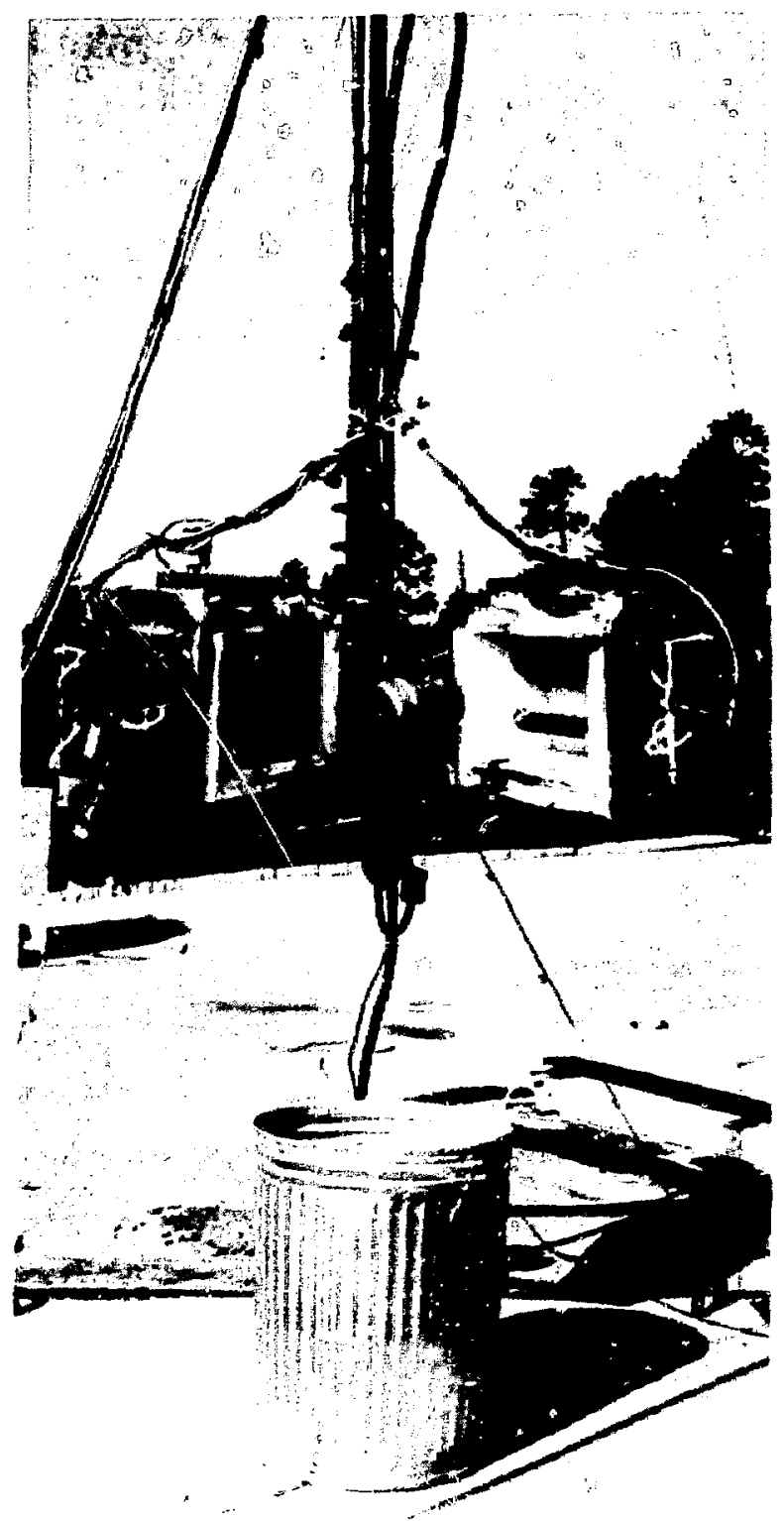

Fig. 6. Heat-quench test setup. 


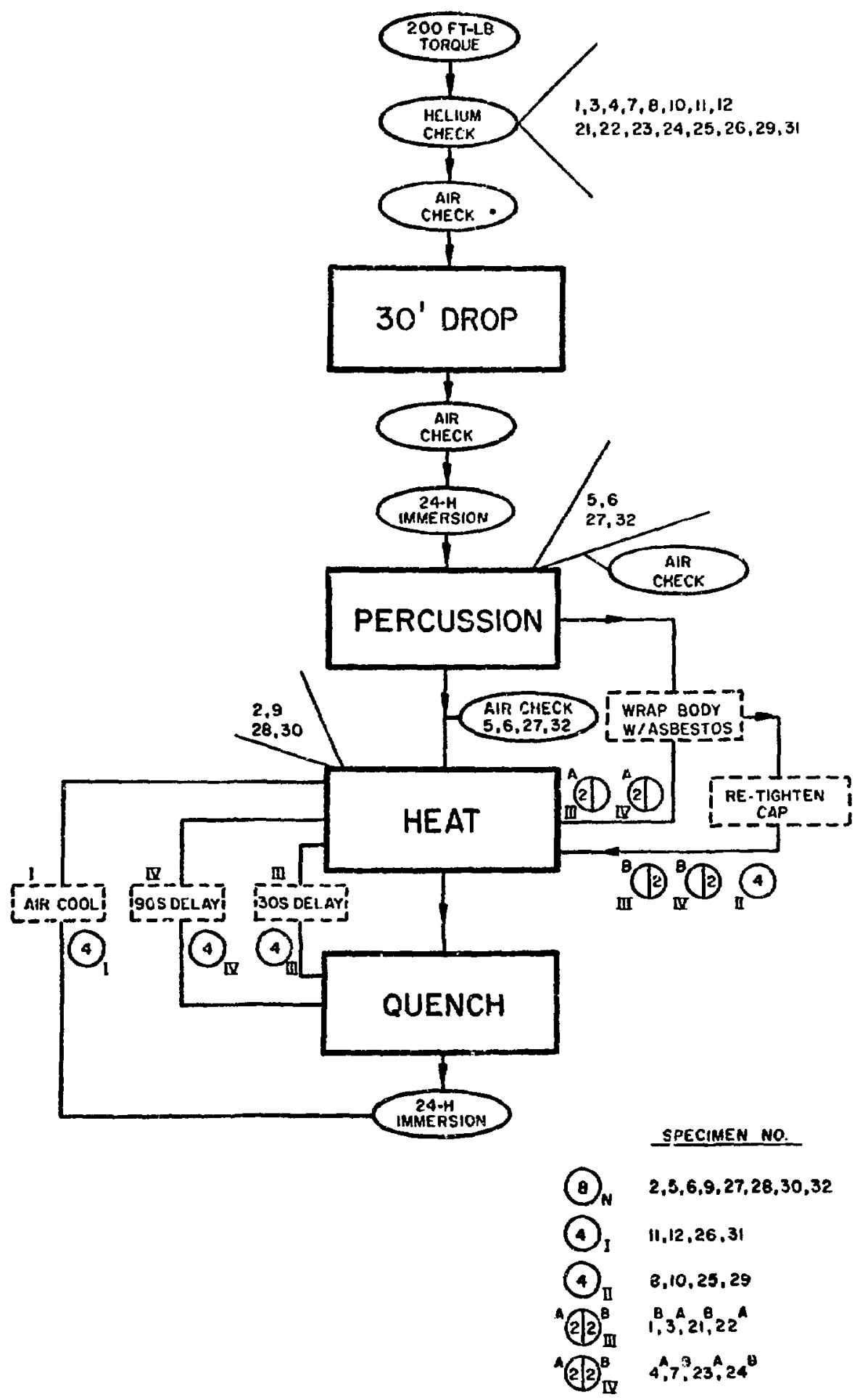

